\title{
Analysis of Sports Policy on The Scope of Recreational Sports in Development Through Sports
}

\author{
$1^{\text {st }}$ Muhammad Gilang Ramadhan \\ Department of Doctor in Physical \\ Education \\ School of Postgraduates \\ Universitas Pendidikan Indonesia \\ Bandung, Indonesia \\ gilangramadhan16@upi.edu \\ $4^{\text {th }}$ Yudha Munajat Saputra \\ Department of Sport Science \\ Faculty of Sport and Health \\ Education \\ Universitas Pendidikan Indonesia \\ Bandung, Indonesia \\ yudhamsaputra@upi.edu
}

\author{
$2^{\text {nd }}$ Sandey Tantra Paramitha \\ Department of Sport Science \\ Faculty of Sport and Health \\ Education \\ Universitas Pendidikan Indonesia \\ Bandung, Indonesia \\ sandeytantra18@upi.edu
}

\author{
$3^{\text {rd }}$ Amung Ma'mun \\ Department of Physical Education \\ School of Postgraduates \\ Universitas Pendidikan Indonesia \\ Bandung, Indonesia \\ amung@upi.edu
}

\begin{abstract}
In development through sports, sports recreation is one of the important instruments in the progress of the nation through sports. The special role of recreational sports is to increase community participation in sports in order to improve physical fitness. The policy is an important key in achieving the paradigm of development through sports, one of which is the focus of developing recreational sports. Therefore, we conducted a literature study in analyzing recreational sports policy in development through sport. Optional Reporting Items for the Systematic Review and Meta-Analysis Methods (PRISMA) were used for the systematic review and meta-analysis. The articles reviewed were 23 articles from 2016-2021. All articles are classified by author, year of publication, journal or conference type, sample size, context, data type, sports policy, and baseline findings. The results of this review show that recreational sports have a positive influence on the development paradigm through sports. Overall, our analysis provides an appropriate reference for further research by identifying research needs in aspects of sport policy in broader national development.
\end{abstract}

Keywords - Sports Policy, Recreational Sports, Instruments, Development.

\section{INTRODUCTION}

Development through sports is a new paradigm that is the latest global issue in the field of sports. Many developed countries have begun to adopt this paradigm. The main reason is to implement sports policy as an instrument in broader national development. Not only in the scope of the sport itself, but the sports policies implemented can contribute to other aspects of national development such as health, fitness to the welfare of its people. Several developed countries that have made movements in embracing the "development through sport" paradigm include South Korea [1], Australia [2], [3] , Japan [4], [5], America [6], English [7] and other developed countries. The sports policies that have been built are outlined in several programs that are implemented comprehensively in these countries. With a sports policy that has a philosophy of this paradigm, it is highly trusted as a national strategic step in nation building, this is because sport has popularity and capacity as a communication platform, sport plays a role in reducing the risk of non-communicable diseases and its potential can be used as a foundation for healthy child development and connect people in social interactions, so that it can be a useful tool to meet various development goals [3]. Several aspects that are built with the sports approach can be integrated through community participation in sports activities.

By implementing the Development through sport paradigm, as South Korea wants to be a truly advanced country, because the success of building elite sports will be much more meaningful when it makes its people more advanced, healthy, and have a quality life, therefore through the 'Dream Together' 
program. As announced, the South Korean government has high hopes for the implementation of the development paradigm through sports by focusing on increasing public participation in sports [1]. The positive relationship between sports participation in adolescents and society at large and the development of life skills is widely recognized by various researchers. However, few studies have explored the role of developing life skills through school-based sports participation, particularly in international settings [8]. In increasing community sports participation, one of them is driven by the sports policy implemented by the government. The development of sports policy in Japan with particular focus illustrates the means of political momentum needed to achieve enforcement of the new laws for sports in Japan [5]. There are three parts that Japan does regarding its sports policy. The first section shows the salience and importance of government and politics in sport which has developed recently. The second section describes the three main points for the enactment of the Basic Law on Sport. The third part maps out the fragmented structure of sports administration in Japan [5]. Then in England with the existence of the Olympic Legacy Plan has been the concern of the government prior to the 2012 London Olympics, in particular, the aspiration to use the event to inspire participation in sport. However, little attention has been paid to the voluntary sector and its role as an agent for conveying legacy aspirations. The new policy for recreational sports sets a clear focus on the use of national regulatory bodies and voluntary sports clubs to provide growth in adult sports participation [9].

In Indonesia, we know that sports based on the Law of the Republic of Indonesia Number 3 of 2005 concerning the National Sports System are mapped into three areas, namely achievement sports, educational sports and recreational sports. The law is an effort by the Indonesian government to carry out national development/development through sports. If we look at the movement of countries that have been considered advanced by the world, such as South Korea, Australia and Japan, actually Indonesia is not far behind regarding the global issues being discussed [10]. This reveals that the importance of the existence of Law no. 3 of 2005 concerning the National Sports System as a basic rule in national development through sports. However, what needs to be underlined is how the implementation in Indonesia itself regarding policies that lead to a paradigm shift from 'sports development' to 'development through sport'. Is it running as it should or no. On the other hand, the fact is that until now sports in Indonesia are still focused on only one scope, namely achievement sports [11]. Therefore, it is necessary to have a massive escort in the concept of paradigm development through sports.
The scope of recreational sports is a type of sport that is very relevant and has great potential by integrating it into the sports activities of the people that are liked and popular. That way, sport will be more popular in the community and will certainly have a direct positive impact on the individual community. One of them is the health aspect which is one of the indicators in the national development of a country, with the country having a healthy society with an above average rating, it means that the country can already be said to be a developed country [12]. To achieve this concept, of course, it must be fought together, starting with the awareness of each individual about the importance of the impact of exercising, to of course the role of the government as a policy maker in implementing it, especially in the policies applied to the sports sector. Recreational sports are actually more appropriate to be aimed at facilitating how people can use leisure time constructively with the ultimate goal of forming a culture of movement and/or sports culture [10].

Currently there is an instrument to measure the sports development index in Indonesia and is known as the Sport Development Index (SDI) [13]. SDI is a measurement method that is claimed as a new alternative to measure the progress of sports development. SDI is a composite index that reflects the success of sports development based on four basic dimensions, namely open space, human resources, community participation, and degree of physical fitness [14]. One way to increase the sports development index is a program that requires citizens to do more active sports every month, week to day, which is of course supported by government policies based on Law no. 3 of 2005 on SKN. Therefore, the root of the problem of the low level of SDI that occurs in Indonesia can be overcome by strengthening the implementation of the rules that must be applied more effectively [14]. In Law no. 3 of 2005 concerning SKN, it has actually been regulated on how to anticipate the problems that are currently happening, as explained above. But the big question is how the concept of implementing sports policies adopted by the government,

In implementing the policy, of course, requires a system to implement the paradigm of 'development through sports' through a policy which is of course designed, determined and applied by the government as the authorized party to do so [15], which of course has a function as a policy maker in the government system of a country. One of them is the government needs to group sports to identify the needs of diverse community support and the role they can play in increasing participation in sports through sports policy [9]. The successful implementation of a policy is determined by three things, namely the government as the policy maker, the implementing agency which is in charge of the policy, and the community as the party affected by the implementation of the policy [16]. 
Therefore, to analyse the success of a policy, it is necessary to look at these three things.

From the brief description above, researchers are very interested in researching sports policies that are applied, especially in the scope of recreational sports, in the process the importance of sport being one aspect of achieving national development. In addition, observations from researchers that the analysis of recreational sports policy has not been studied scientifically. Therefore, this research is a new product in research in the field of sports.

\section{THEORETICAL FRAMEWORK}

\section{A. Recreational Sports}

Recreational sports are closely related to the sports community which is an association of people who like a certain type of recreational sport. It is also undeniable that there is a concept launched by the government regarding 'sport for all' or what we usually know as sport for all. In other words, it means that sports must be able to become mass in the community or known as socializing sports or cultivating the community. There are three main contributions to the development of recreational sports. First, it caters to all groups and individuals who are interested in a particular sport. Second, the organization's management focuses on developing sports at the basic level in both recreational and competitive forms. Third, the organization's management is obliged to improve the welfare of the community through increasing sports participation [17].

In the UK recreational sports are used to increase community social engagement with educational and occupational approaches to sport [18]. This concept is specifically focused on young people as very important human beings for a country as agents of the future for that country. However, with the concept that has been applied, it is very necessary to carry out an evaluation, and this is what the UK has done. Over the past decade, a growing number of academics have called for program evaluations that present the conditions for how and why exercise-based interventions can contribute to broader social outcomes [19]. Central to this form of evaluation is the need to examine the mechanisms by which program outcomes can be achieved and take into account the context of the intervention by recognizing that program success can be limited by contextual factors especially regarding social engagement [20].

\section{B. Development Through Sport}

Development through sport is a global issue that has become a paradigm in the field of sports, which is being discussed and has been widely applied in developed countries, and means that sport has a role as one of the important aspects in terms of development at the international, national and regional levels [21].
This is different from the paradigm of 'sports development' which means that sport is an object that must be developed, and of course only focus on the sport itself to be developed [22]

The development in question is the development of other fields that become indicators in the development of a country. One of them refers to indicators from the Human Development Index (HDI). In the HDI indicator, the measurement is three dimensions, consisting of the dimensions of long life and healthy living, the dimensions of knowledge, and the dimensions of a decent standard of living viewed from an economic point of view. In this dimension of longevity and healthy living, exercise will be an aspect that influences the improvement of these dimensions. Therefore, development in this sense does not mean development which means building a physical object such as a building and others. However, the development in question is development that leads to all aspects that become indicators of national development.

The 'Development through sport' paradigm is a concept that uses sports, physical activity and games as tools to facilitate social improvement in countries and communities targeted for development. International movements supporting development through sport operate within two overlapping but distinct discursive frameworks: sport and play as universal and integrative social practices, and international development as the delivery of good aid, goods and expertise from the north, the 'First World' to the south 'Third World'. The development paradigm through sport functions in reconstructing certain knowledge: White people as the subject position of virtue, rationality and expertise, are asserted in contrast to the marginalized body color [23]

\section{METHOD}

This literature review research uses the Preferred Reporting Items for the Systematic Review and MetaAnalysis Method (PRISMA) introduced by Moher et al. (2009). PRISMA is a method that can assist authors in reviewing literature and meta-analysis properly and helps authors to analyse more systematically such as Moher et al. (2009, 2010, 2016), Hutton et al. (2016), Shamseer et al. (2015) and Stewart et al. (2015). Systematic review is a search for evidence from scientific research that has been carried out by several researchers which must be collected and analysed scientifically using a structured procedure based on objectivity which will certainly distinguish it from other researchers in providing views on an object under study. In addition, by using this literature review method, one must be more careful in choosing to present research hypotheses [30]. 


\section{A. Search Strategies}

At this stage, we select articles that are relevant to the discussion related to recreational sports policies published in indexed journals. The literature search used the keywords "sports policy", "recreational sports", "development through sport", and "recreational sports policy in development through sport". Articles searched for from January 2016 to June 2021, the time range was chosen to provide the latest analysis results and relate to current issues. Based on the search strategy, there were 103 articles that were entered in management software such as Mendeley. By using the PRISMA Method, the next step is to eliminate automatic duplication using software. After the duplication remove were done, where 17 articles have been removed. Finally, 86 articles were selected after the first stage was carried out.

\section{B. Data Inclusion and Exclusion}

Eligibility criteria are needed to select articles as reported by [31]. Articles are filtered based on inclusion and exclusion criteria as shown in table 1. Based on the exclusion criteria according to the requirements that the criteria include theses, book chapters, short reports, non-empirical studies and nonEnglish papers have been removed. In other words, only international journals are included in the inclusion criteria. Based on this stage, there are 21 articles that are not in accordance with the topic of discussion in this study, so there are 65 articles. The next step is to investigate the titles and abstracts based on their relevance to the subject of the articles related to recreational sport policy in development through sport. Results from the investigation of irrelevant articles were omitted. Overall, there are 23 articles that meet the inclusion criteria and are relevant to the object of the literature review research.
TABLE 1. Inclusion and exclusion data criteria

\begin{tabular}{|l|l|}
\hline \multicolumn{1}{|c|}{ Inclusion Criteria } & \multicolumn{1}{|c|}{ Exclusion Criteria } \\
\hline English & $\begin{array}{l}\text { Articles written in other } \\
\text { languages }\end{array}$ \\
\hline $\begin{array}{l}\text { Time: January 2016 to } \\
\text { June 2021 }\end{array}$ & Before 2016 \\
\hline $\begin{array}{l}\text { Publish in international } \\
\text { journals }\end{array}$ & $\begin{array}{l}\text { theses, book chapters, } \\
\text { short reports, non- } \\
\text { empirical studies and } \\
\text { non-English papers }\end{array}$ \\
\hline $\begin{array}{l}\text { Relating to recreational } \\
\text { sports policy in } \\
\text { development through } \\
\text { sport }\end{array}$ & $\begin{array}{l}\text { Not reclated to } \\
\text { recreational den sports } \\
\text { policies in development } \\
\text { through sports }\end{array}$ \\
\hline
\end{tabular}

\section{Data Extraction and Analysis}

In the final stage, 23 articles that will contribute to this literature review study are tested. These articles were tested and selected based on important information in answering the research object of the literature review. Based on the required information, we decided on several classifications and criteria referring to the object of research.

Data extraction is designed to classify, analyse and synthesize the articles that we find based on their specification criteria. Then, based on the data extraction analysis, we can get the best results and recommendations. Criteria are the author, year of publication, type of journal, sample size, context, data type, sport policy, and basic findings. After reviewing the articles, 23 articles were collected that were published between January 2016 and June 2021, based on international journals that met the inclusion criteria. All articles have been read and selected in detail relating to recreational sports policies in development through sports. But besides that, it is still carried out according to the PRISMA method even though choosing the right article takes a lot of time but because of the specially structured nature of this method, it is ensured that the most appropriate and relevant article related to the subject, a literature review has been selected. 


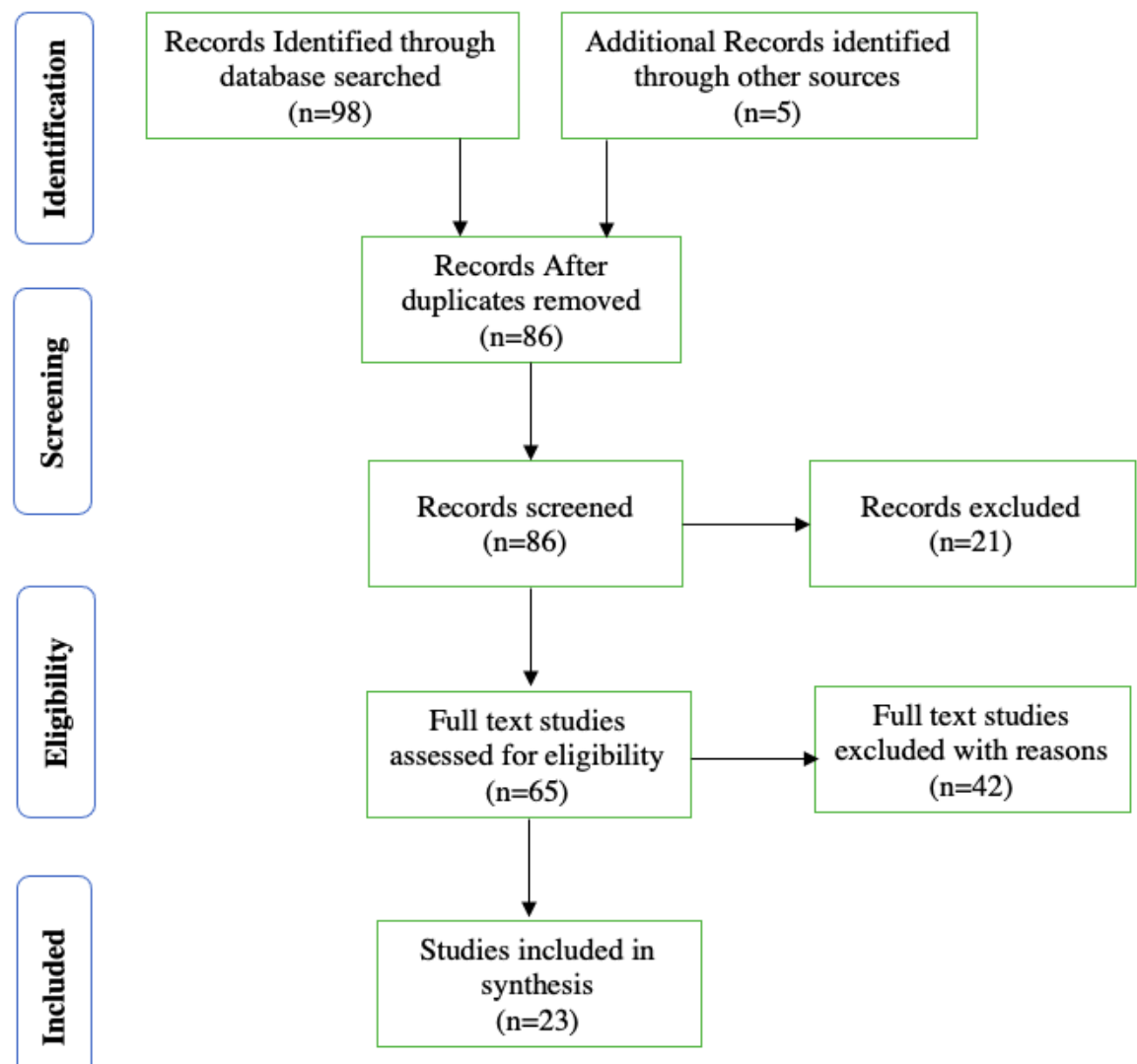

Fig 1. PRISMA Flowchart detailing the steps followed in the selection of studies systematic literature review

\section{RESULTS}

The findings from the analysis and synthesis related to the articles are presented in this section. Based on a systematic review and results from metaanalysis of data, as well as the context of sports recreation policy in development through sport has been found. Therefore, the following are the results of the findings in accordance with the requirements in the analysis of articles that are included in the categories related to the object of this study.

\section{A. The frequency of articles published over the last few years}

The articles reviewed in this literature study amounted to 23 articles that met the inclusion criteria. Articles amounted to $22 \%$ of the total articles retrieved through a search database based on keywords and the year the article was published between the period January 2016 to June 2021 as shown in Figure 2. The graph shows that there was a significant increase in articles published in 2019, which amounted to $39 \%$. Although the graph shows that there is a decrease in articles published in 2020 and 2021. This proves that at the initial research stage this was completed. Although actually in 2021 there is still time left to add published articles related to recreational sports policies in development through sports. In addition, significant progress has occurred in several years, namely five articles in 2018, and nine articles in 2019. Therefore, based on these results, it proves that there has been an increase in studies related to recreational sports policies in development through sports. 


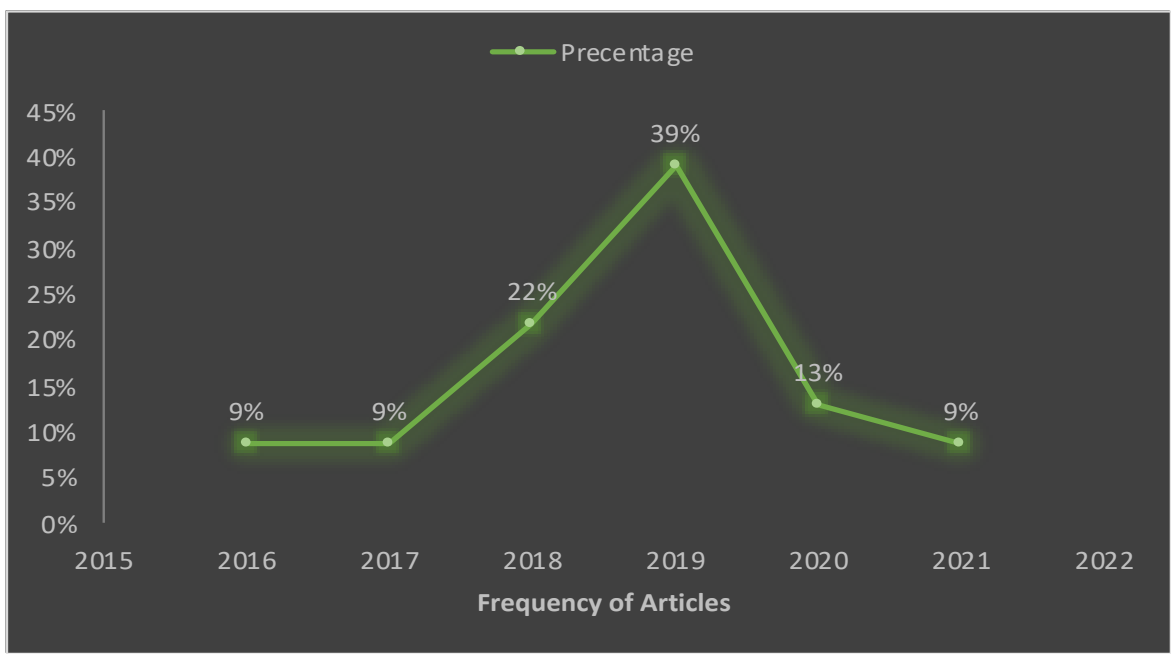

Fig 2. Frequency of articles based on publication year

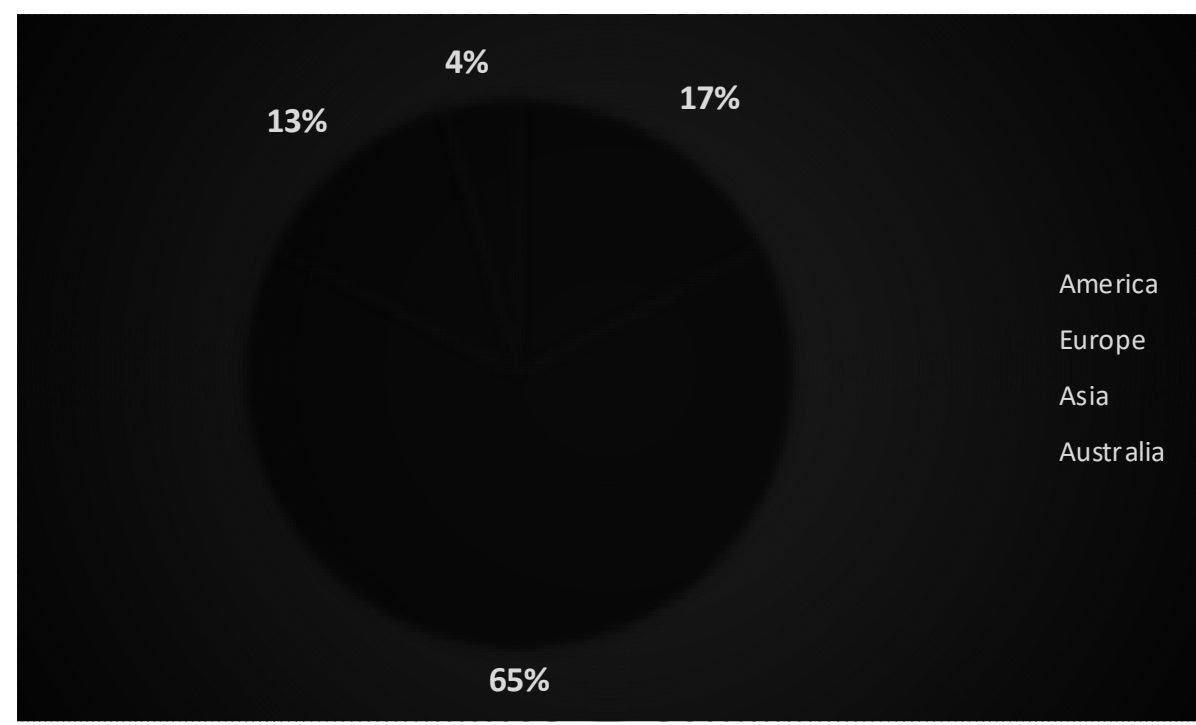

Fig 3. Articles distribution based on research area

\section{B. Distribution of articles by research area}

The articles reviewed in this literature review are taken from 23 articles published in international journals from 2016 to 2021 from various parts of the world. The distribution of published articles based on the research area (continent) is presented in Figure 3.

As can be seen in Figure 3, the published scientific articles are dominated by the European continent with $65 \%$ of the distribution of published articles over the last five years. Then America is $17 \%$, Asia is $13 \%$ and Australia is $4 \%$. This indicates that European scientists are discussing more about recreational sports policies in development through sports.

\section{Distribution of articles by context}

In the distribution of articles based on context, several studies related to recreational sports policies in development through sports were found, divided into several aspects, including:

- Recreational Sports [32]-[35]

- $\quad$ Sports Policy [36]-[40]

- Development Through Sport [41]

- Sport Policy, Development Through Sport [6], [11], [21], [42], [43]

- Sport Policy, Recreational Sport [4], [7], [18], [44]-[47] 
Based on these findings, it proves that the study related to recreational sports policy in development through sports has several and various aspects, especially in the aspect of Sport Policy, Recreational Sport. The distribution of articles by context is presented in Figure 4.

\section{Distribution of articles by data type}

Based on the type of data in each article, several methods are often used in this study, including:

- $\quad$ Case Study [4], [11], [39], [43]

- Comparative Analysis [6], [18], [21], [35], [37], [38], [42], [44]
- $\quad$ Experiment [33], [40], [47]

- Mix Methods [7]

- $\quad$ Survey [32], [34], [45]

- $\quad$ Systematic Literature Review [36], [41], [46], [48]

The method most often used in research related to the context of recreational sports policy in development through sports is a comparative analysis study, where the study is compared to the increase in community participation in sports. The distribution of articles by data type is presented in Figure 5.

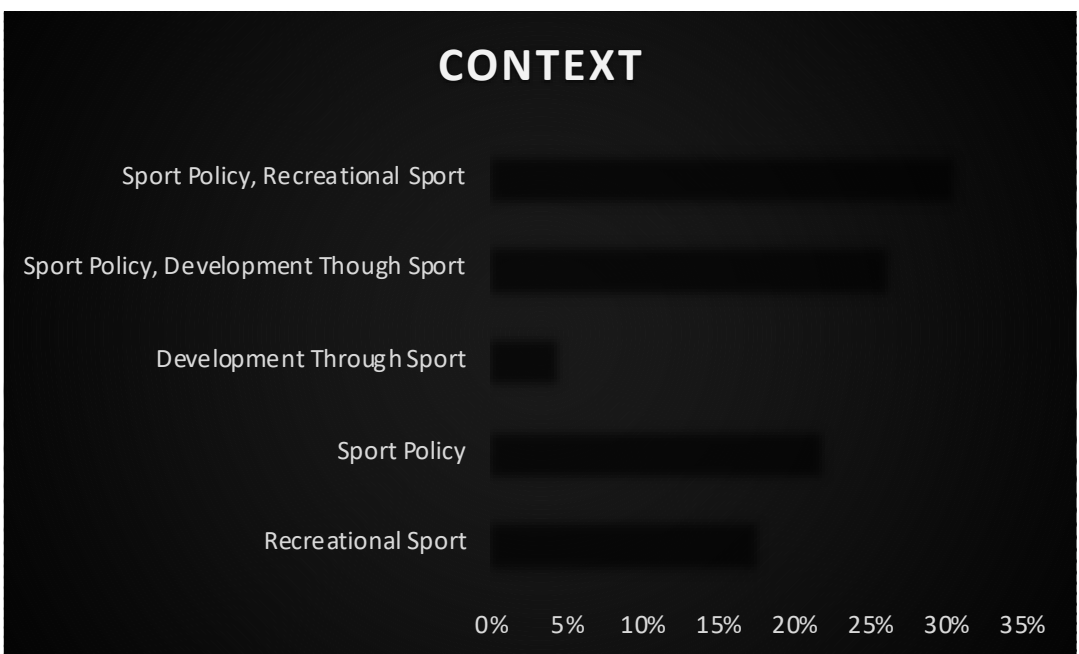

Fig 4. Articles distribution based on context

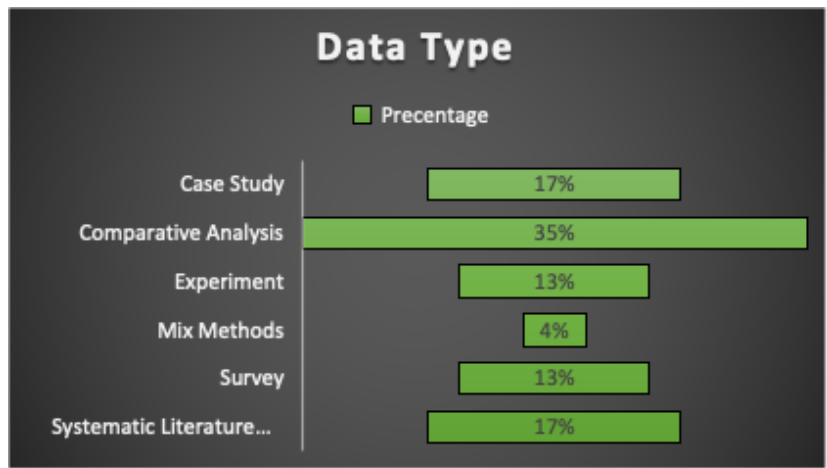

Fig 5. Articles distribution based on data type

\section{E. Distribution of articles based on basic findings}

The basic findings analysed from this literature review are about how the impact of implementing sports policies, especially the scope of recreational sports on the development paradigm through sports. Therefore, the impact of our recreational sports policy is examined based on different articles on whether it 
has a positive impact or not. The results of the study showed that $100 \%$ of the articles reviewed said that the implementation of recreational sports policies had a positive impact on development through sports. This means that recreational sports can be an instrument in the development of a nation at the national and international levels. The positive influence of the policy in the sphere of recreational sports on development is presented in Figure 6.

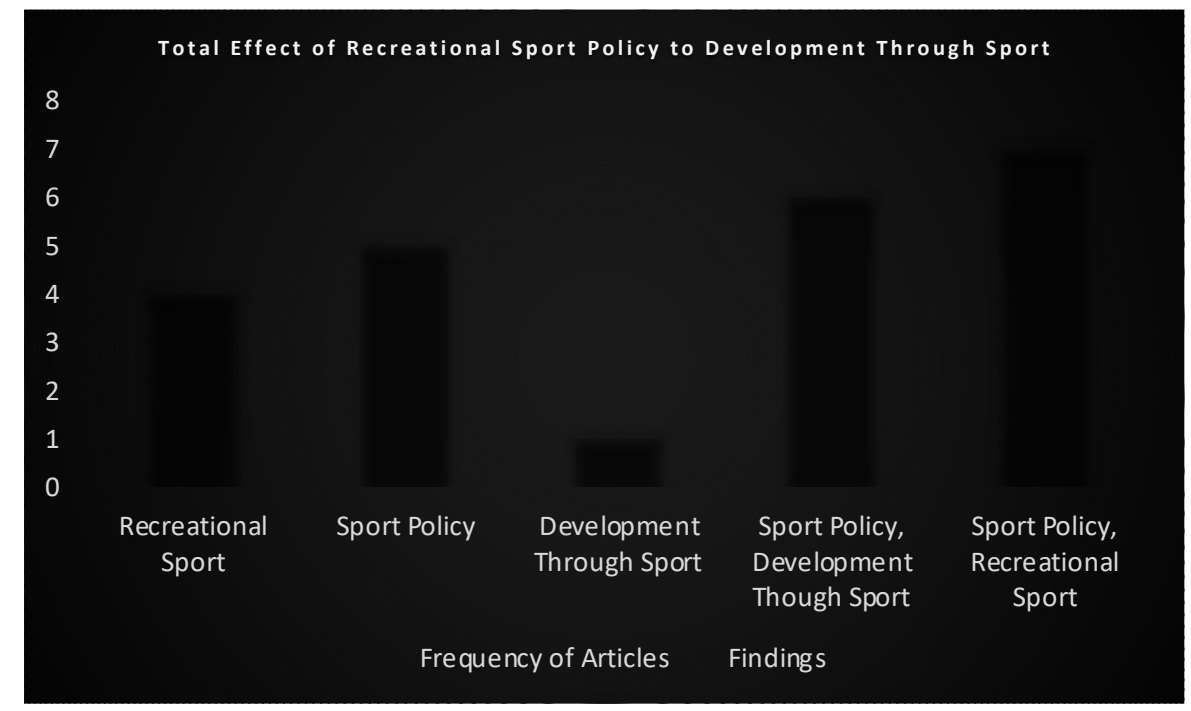

Fig 6. Articles distribution based on basic findings

\section{DISCUSSION}

This literature review is designed to review the implementation of recreational sports policies on their impact on development in other aspects through recreational sports platforms. Several previous studies have noted the importance of exercise as a broader development instrument. Based on the results, we can see that this research study is one of the valuable studies to prove the positive impact of recreational sports on development through sports. In this review, we identified 23 articles that are relevant to the object of research related to policies in the scope of recreational sports from 2016 to 2021 in order to obtain the latest views and current issues, especially in the paradigm of development through sports.

The relationship of development using sport as an instrument is to assess the improvement of one of the indicators in the human development index (HDI) [11]. In the HDI it is stated that one of the indicators is the dimension of long and healthy life, apart from other indicators, namely dimensions of knowledge, and dimensions of decent living standards from an economic point of view [49]. Therefore, the importance of the role of sport is to focus on making people able to maintain their health so that it will increase life expectancy.

In this study, the researcher used an appropriate classification based on the PRISMA method. One of the several classifications is about classifying the number of articles published each year. In recent years there has been an increase in the use of recreational sport policies to influence development more broadly. It can be seen that the increase in published articles from 2016 and 2017 which was only 9\% until there was a significant increase in 2019 of $39 \%$. Although in 2020 and 2021 there will be a decline in the publication of articles on recreational sports policies in development through sports, due to the global COVID-19 pandemic [50]-[52]

The second classification is the distribution of published articles based on the research area (continent). Based on the findings, it is said that researchers from the European continent more often study related to the implementation of recreational sports policies in their country's national development in other fields. The object of this research is widely studied in Europe because in fact in Europe the majority of countries are included in the criteria of developed countries, when compared to other continents. In addition, the influence of the characteristics of developed countries themselves causes more awareness of the importance of the role of sport in development through sports [42], [48].

The third classification is the distribution of articles based on context which is divided into five aspects that are the focus of several researchers in reviewing recreational sports policies in development 
through sports. Some of these aspects are reviewed based on variables that are closely related to the object of this research. By focusing on aspects of recreational sport, sport policy, to development through sport, researchers will be more systematic in analysing the results of implementing recreational sports policies. In this review, it was found that with a focus on sport policy studies and recreational sports by $30 \%$, it proved that studies on objects with this focus greatly influenced development in other fields [4], [7], [18], [44]-[47].

The next classification is about the type of data in each article which found several methods such as Case Study, Comparative Analysis, Experiment, Mix Methods, Survey, Systematic Literature Review. Based on the findings of the review, the most widely used method is comparative analysis, which is a study compared to increasing community participation in sports. This is based on the fact that this recreational sport has the main purpose of using it to promote sports. That way, the degree of public health will automatically increase which will certainly increase one of the HDI indicators, namely the dimensions of health and life expectancy [6], [18], [21], [35], [37], [38], [42], [44].

The last classification is about Basic Findings with the aim of knowing how the impact of implementing sports policies, especially the scope of recreational sports on the paradigm of development through sports. By analysing and synthesizing 23 articles that have met the criteria, it was found that the impact of the implementation of this recreational sports policy resulted in a positive influence in building the nation through sports that could improve other aspects, especially in the health aspect [53]. Besides, according to Misener et al. (2013) with the implementation of the recreational sports policy, it will have an impact on three main contributions that will be felt by the community, namely first, serving all groups and individuals who are interested in a particular sport. Second, focus on the development of sports at the basic level in both recreational and competitive forms. Third, it can improve people's welfare through increased sports participation.

\section{CONCLUSION}

This literature review identifies studies related to the object of implementing recreational sports policies on development through sports. This study uses the PRISMA method as the basis for analysis and synthesis of several relevant studies. In this case, several databases have been selected from several articles published for the period January 2016 to June 2021.To meet the objectives of this study, all articles found were classified by the author, year of publication, type of journal, sample size, context, data type, sport policy, and basic findings. The results of this study indicate that the level of published articles has increased even though in several years it has decreased again due to the current state of the covid19 pandemic. Another result obtained from this research is knowing about the impact of implementing recreational sports policies on development through sports, and it turns out that the findings show that recreational sports policies have $100 \%$ positive impact on development that improves other aspects, especially health.

\section{ACKNOWLEDGMENT}

The authors would like to express their thanks to the Department of Doctor in Physical Education, School of Postgraduates Universitas Pendidikan Indonesia, Dr. Setiabudhi Street No. 229 Bandung, Indonesia.

\section{REFERENCES}

[1] J. P. Ha, K. Lee, and G. Ok, "From Development of Sport to Development through Sport: A Paradigm Shift for Sport Development in South Korea," Int. J. Hist. Sport, vol. 32, no. 10, pp. 1262-1278, 2015, doi: $10.1080 / 09523367.2015 .1062756$.

[2] S. Geidne et al., "Health Promotion Interventions in Sports Clubs: Can We Talk About a Setting-Based Approach? A Systematic Mapping Review," Health Education and Behavior. 2019, doi: 10.1177/1090198119831749.

[3] A. S. Commission, A. Agency, and I. Development, "A joint strategy of the Australian Sports Commission (ASC) and the Australian Agency for International Development (AusAID) 2013-2017 1,”pp. 2013-2017, 2013.

[4] K. Aizawa, M. Orr, Y. Inoue, J. Nagazumi, and M. Yoshida, "Leveraging sport events for sustainable sport participation: how schools contribute to sport development through events," Eur. Sport Manag. Q., 2021, doi: 10.1080/16184742.2021.1910326.

[5] M. Y. Y. Yamamoto, "Development of the sporting nation: Sport as a strategic area of national policy in Japan," Int. J. Sport Policy, vol. 4, no. 2, pp. 277-296, 2012, doi: 10.1080/19406940.2012.685489.

[6] I. Lindsey and P. Darby, "Sport and the Sustainable Development Goals: Where is the policy coherence?," Int. Rev. Sociol. Sport, 2019, doi: $10.1177 / 1012690217752651$.

[7] H. Kumar, A. E. Manoli, I. R. Hodgkinson, and P. Downward, "Sport participation: From policy, through facilities, to users' health, well-being, and social capital," Sport Manag. Rev., 2018, doi: 10.1016/j.smr.2018.01.002.

[8] L. A. Hayden, M. A. Whitley, A. L. Cook, A. Dumais, M. Silva, and A. Scherer, "An exploration of life skill development through sport in three international high schools," Qual. Res. Sport. Exerc. Heal., vol. 7, no. 5, pp. 
759-775, 2015, doi: 10.1080/2159676X.2015.1011217.

[9] T. May, S. Harris, and M. Collins, "Implementing community sport policy: Understanding the variety of voluntary club types and their attitudes to policy," Int. J. Sport Policy, vol. 5, no. 3, pp. 397-419, 2013, doi: 10.1080/19406940.2012.735688.

[10] A. Ma'mun, "Pembudayaan Olahraga dalam Perspektif Pembangunan Nasional Konsep, Strategi, dan Implementasi Kebijakan," Sosio Humanika, 2016.

[11] M. G. Ramadhan, A. Ma'mun, and A. Mahendra, "Implementasi Kebijakan Olahraga Pendidikan sebagai Upaya Pembangunan Melalui Olahraga Berdasarkan Undang-Undang Sistem Keolahragaan Nasional," $J$. Terap. Ilmu Keolahragaan, 2020, doi: 10.17509/jtikor.v5i1.23824.

[12] N. F. Rowe, "Sporting capital: a theoretical and empirica analysis of sport participation determinants and its application to sports development policy and practice," Int. J. Sport Policy, vol. 7, no. 1, pp. 43-61, 2015, doi: 10.1080/19406940.2014.915228.

[13] KEMENPORA, "Laporan Kinerja KEMENPORA 2017," Lap. Kinjerja Kementrian Pemuda dan Olahraga RI, 2018, doi: 10.1017/CBO9781107415324.004

[14] T. C. Mutohir and A. Maksum, "Sport Development Index," Jakarta: Kemenpora, 2007.

[15] H. J. Won and E. Hong, "The development of sport policy and management in South Korea," Int. J. Sport Policy, vol. 7, no. 1, pp. 141-152, 2015, doi: 10.1080/19406940.2014.900104.

[16] D. C. Korten, "Community Organization and Rural Development: A Learning Process Approach," Public Adm. Rev., vol. 40, no. 5, p. 480, 1980, doi: $10.2307 / 3110204$.

[17] K. Misener, A. Harman, and A. Doherty, "Understanding the local sports council as a mechanism for community sport development," Manag. Leis., vol. 18, no. 4, pp. 300-315, 2013, doi: 10.1080/13606719.2013.809185.

[18] H. Morgan, A. Parker, and W. Roberts, "Community sport programmes and social inclusion: what role for positive psychological capital?," Sport Soc., vol. 22, no. 6, pp. 1100-1114, 2019, doi: $10.1080 / 17430437.2019 .1565397$

[19] F. Coalter, "'There is loads of relationships here': Developing a programme theory for sport-for-change programmes," Int. Rev. Sociol. Sport, 2013, doi $10.1177 / 1012690212446143$

[20] A. S. Fox, J. Bonacci, S. G. McLean, and N. Saunders, "Efficacy of ACL injury risk screening methods in identifying high-risk landing patterns during a sportspecific task," Scand. J. Med. Sci. Sport., 2017, doi: $10.1111 / \mathrm{sms} .12715$.

[21] C. Cameron, “'Happiness' and 'Holes': Questions for the Future of Development through Sport," Can. J. Dev. Stud. / Rev. Can. d'études du développement, vol. 27, no. 4, pp. 567-572, 2018, doi: $10.1080 / 02255189.2006 .9669174$.
M. Dowling, P. Brown, D. Legg, and J. Grix, "Deconstructing comparative sport policy analysis: assumptions, challenges, and new directions," Int. J. Sport Policy Polit., vol. 10, no. 4, pp. 687-704, 2018, doi: 10.1080/19406940.2018.1530276.

[23] S. C. Darnell, M. Chawansky, D. Marchesseault, M. Holmes, and L. Hayhurst, "The State of Play: Critical sociological insights into recent 'Sport for Development and Peace' research," Int. Rev. Sociol. Sport, vol. 53, no. 2, pp. 133-151, 2018, doi: 10.1177/1012690216646762.

[24] D. Moher et al., "Preferred reporting items for systematic reviews and meta-analyses: The PRISMA statement," PLoS Med., vol. 6, no. 7, 2009, doi: 10.1371/journal.pmed.1000097.

[25] D. Moher, A. Liberati, J. Tetzlaff, and D. G. Altman, "Preferred reporting items for systematic reviews and meta-analyses: The PRISMA statement," Int. J. Surg., 2010, doi: 10.1016/j.ijsu.2010.02.007.

[26] D. Moher et al., "Preferred reporting items for systematic review and meta-analysis protocols (PRISMA-P) 2015 statement," Rev. Esp. Nutr. Humana y Diet., 2016, doi: 10.1186/2046-4053-4-1

[27] B. Hutton, F. Catalá-López, and D. Moher, "ARTICLE IN PRESS G Model Artículo especial The PRISMA statement extension for systematic reviews incorporating network meta-analysis: PRISMA-NMA," Med. Clin. (Barc)., 2016

[28] L. Shamseer et al., "Preferred reporting items for systematic review and meta-analysis protocols (prisma-p) 2015: Elaboration and explanation,” BMJ (Online). 2015, doi: $10.1136 / \mathrm{bmj} . \mathrm{g} 7647$.

[29] L. A. Stewart et al., "Preferred reporting items for a systematic review and meta-analysis of individual participant data: The PRISMA-IPD statement," JAMA Journal of the American Medical Association. 2015, doi: 10.1001/jama.2015.3656.

[30] M. Ressing, M. Blettner, and S. J. Klug, "Systematic literature reviews and meta-analyses: part 6 of a series on evaluation of scientific publications," Dtsch. Arztebl. Int., 2009 .

[31] H. Ahmadi, M. Gholamzadeh, L. Shahmoradi, M. Nilashi, and P. Rashvand, "Diseases diagnosis using fuzzy logic methods: A systematic and meta-analysis review," Computer Methods and Programs in Biomedicine. 2018, doi: 10.1016/j.cmpb.2018.04.013.

[32] K. Orr, M. B. Evans, K. A. Tamminen, and K. P. ArbourNicitopoulos, "A Scoping Review of Recreational Sport Programs for Disabled Emerging Adults," Res. Q. Exerc. Sport, vol. 91, no. 1, pp. 142-157, 2020, doi: $10.1080 / 02701367.2019 .1653432$.

[33] K. Alexandris, J. Du, and D. Funk, "The influence of sport activity personality on the stage-based development of attitude formation among recreational mountain skiers," Manag. Sport Leis., vol. 21, no. 4, pp. 218-238, 2016, doi: 10.1080/23750472.2016.1255155

[34] T. St Quinton and J. A. Brunton, "The Key Psychological Beliefs Underlying Student Participation in Recreational Sport," Recreat. Sport. J., vol. 44, no. 1, pp. 38-50, 2020, doi: $10.1177 / 1558866120932179$.

[35] C. Bean, M. Shaikh, S. Kramers, and T. Forneris, "Does context matter? Unpacking differences in program quality 
and developmental experiences across competitive and recreational youth sport," Int. J. Sport. Sci. Coach., 2021, doi: $10.1177 / 17479541211001879$.

[36] S. Chalmers and O. Jay, "Australian community sport extreme heat policies: Limitations and opportunities for improvement," J. Sci. Med. Sport, vol. 21, no. 6, pp. 544 548, 2018, doi: 10.1016/j.jsams.2018.01.003.

M. Dowling, P. Brown, D. Legg, and J. Grix, "Deconstructing comparative sport policy analysis: assumptions, challenges, and new directions," Int. J. Sport Policy Polit., vol. 10, no. 4, pp. 687-704, 2018 , doi: 10.1080/19406940.2018.1530276.

[38] A. Ma'mun, "Governmental Roles in Indonesian Sport Policy: From Past to Present," Int. J. Hist. Sport, 2019, doi: 10.1080/09523367.2019.1618837.

[39] J. M. Patatas, V. De Bosscher, I. Derom, and J. De Rycke, "Managing parasport: An investigation of sport policy factors and stakeholders influencing para-athletes' career pathways," Sport Manag. Rev., vol. 23, no. 5, pp. 937-951, 2020, doi: 10.1016/j.smr.2019.12.004.

[40] G. J. Jones, M. Hyun, M. B. Edwards, J. Casper, J. N. Bocarro, and J. Lynch, "Is 'school sport' associated with school belongingness? Testing the influence of school sport policy," Sport Manag. Rev., vol. 23, no. 5, pp. 925936, 2020, doi: 10.1016/j.smr.2019.12.003.

[41] H. Collison, "The commonwealth guide to advancing development through sport," Sport Soc., vol. 21, no. 9 , pp. 1493-1494, 2018, doi: $10.1080 / 17430437.2018 .1434461$

[42] D. R. Black, "The challenges of articulating 'top down' and 'bottom up' development through sport," Third World Themat. A TWQ J., vol. 2, no. 1, pp. 7-22, 2017, doi: 10.1080/23802014.2017.1314771.

[43] D. W. Walsh, B. C. Green, T. Harrison, and M. T Bowers, "'Sport as a Resource Caravan': Understanding How Adults Utilize Sport as a Developmental Tool," $J$. Glob. Sport Manag., vol. 0, no. 0, pp. 1-23, 2019, doi: 10.1080/24704067.2019.1669204.

[44] L. Chalip, B. C. Green, M. Taks, and L. Misener, "Creating sport participation from sport events: making it happen," Int. J. Sport Policy, vol. 9, no. 2, pp. 257-276, 2017, doi: 10.1080/19406940.2016.1257496.

F. J. M. Mölenberg, F. de Waart, A. Burdorf, and F. J. van Lenthe, "Hosting elite sport events to target recreational sport participation: an interrupted time series analysis," Int. J. Sport Policy Polit., vol. 12, no. 4, pp. 531-543, 2020, doi: 10.1080/19406940.2020.1839530.

[46] C. Mackintosh, G. Griggs, and R. Tate, "Understanding the growth in outdoor recreation participation: an opportunity for sport development in the United Kingdom," Manag. Sport Leis., vol. 23, no. 4-6, pp. 315335, 2018, doi: 10.1080/23750472.2019.1595093.

[47] C. Lane et al., "Healthy vending contracts: Do localized policy approaches improve the nutrition environment in publicly funded recreation and sport facilities?," Prev. Med. Reports, vol. 16, no. August, p. 100967, 2019, doi: 10.1016/j.pmedr.2019.100967.

[48] N. L. Holt et al., "A grounded theory of positive youth development through sport based on results from a qualitative meta-study," Int. Rev. Sport Exerc. Psychol., vol. 10, no. 1, pp. 1-49, 2017, doi: 10.1080/1750984X.2016.1180704.

[49] S. Morse and S. Morse, "Human Development Index," in The Rise and Rise of Indicators, 2019.

[50] A. Hammami, B. Harrabi, M. Mohr, and P. Krustrup, "Physical activity and coronavirus disease 2019 (COVID19): specific recommendations for home-based physical training," Manag. Sport Leis., vol. 0, no. 0, pp. 1-6, 2020, doi: 10.1080/23750472.2020.1757494.

[51] N. Yousfi, N. L. Bragazzi, W. Briki, P. Zmijewski, and K. Chamari, "The COVID-19 pandemic: How to maintain a healthy immune system during the lockdown A multidisciplinary approach with special focus on athletes," Biol. Sport, vol. 37, no. 3, pp. 211-216, 2020, doi: 10.5114/biolsport.2020.95125.

[52] M. Schnitzer, S. E. Schöttl, M. Kopp, and M. Barth, "COVID-19 stay-at-home order in Tyrol, Austria: sports and exercise behaviour in change?," Public Health, vol. 185, pp. 218-220, 2020, doi: 10.1016/j.puhe.2020.06.042.

[53] L. Mansfield, T. Kay, N. Anokye, and J. Fox-Rushby, “A qualitative investigation of the role of sport coaches in designing and delivering a complex community sport intervention for increasing physical activity and improving health," BMC Public Health, 2018, doi: 10.1186/s12889-018-6089-y. 